\title{
UPAYA HUKUM KONSUMEN TERHADAP PENYALAHGUNAAN SUNTIK VITAMIN C ILEGAL PADA SALON KECANTIKAN DI KECAMATAN TAMPAKSIRING*
}

Oleh:

\author{
Desak Nyoman Dwi Indah Parwati** \\ Dr. I Ketut Westra,SH., $\mathrm{MH}^{* * *}$ \\ Program Kekhususan Hukum Bisnis Fakultas Hukum \\ Universitas Udayana
}

\begin{abstract}
ABSTRAK
Penulisan ini mempunyai judul "Upaya Hukum Konsumen Terhadap Penyalahgunaan Suntik Vitamin c Ilegal Pada Salon Kecantikan di Kecamatan Tampaksiring”. Banyaknya usaha-usaha kecantikan yang menawarkan harga murah menyebabkan konsumen tidak teliti untuk memilih jasa kecantikan yang aman sehingga menyebabkan kerugian bagi konsumen karena pelaku menjual produk yang tidak memiliki ijin edar atau illegal. Terjadinya kerugian yang diderita oleh konsumen menjadi tanggung jawab pelaku usaha untuk dapat memberikan ganti rugi sebagai suatu kewajiban pelaku usaha.

Metode penelitian yang digunakan dalam karya ilmiah ini yaitu metode penelitian hukum empiris dengan jenis pendekatan peraturan perundang-undangan. Pendekatan yuridis empris adalah suatu pendekatan yang menganalisa kesenjangan antara

${ }^{*}$ Makalah ilmiah ini merupakan makalah ilmiah diluar ringkasan skripsi dengan judul "Perlindungan Hukum Bagi Konsumen Terhadap Penyalahgunaan Suntik Vitamin c Pada Salon Kecantikan di Kecamatan Tampaksiring"

** Penulis pertama adalah Desak Nyoman Dwi Indah Parwati, Mahasiswi Fakultas Hukum Universitas Udayana, e-mail : duwik.indah@yahoo.co.id

${ }^{* * *}$ Penulis kedua adalah Dr. I Ketut Westra, SH., MH, Dosen pengajar bidang Hukum Bisnis Fakultas Hukum Universits Udayana
\end{abstract}


norma dan perilaku masyarakat (kesenjangan antara das sollen dan das sein.

Hasil penelitian yang didapat adalah bentuk Upaya hukum konsumen terhadap penyalahgunaan suntik vitamin c pada salon kecantikan di Kecamatan Tampaksiring dimana pelaku usaha tidak mau membayar ganti rugi kepada konsumen dan bentuk upaya penyelesaian kasus yang dilakukan oleh konsumen yaitu dengan meminta ganti kerugian kepada pelaku usaha salon kecantikan.

\section{KATA KUNCI : Upaya Hukum, konsumen, suntik vitamin c}

\section{ABSTRACT}

This writing has the title "Consumer Legal Efforts Against Abuse of Vitamin C Injection Illegal at Beauty Salons in Tampaksiring District". The many beauty businesses that offer low prices cause consumers not to be careful in choosing safe beauty services that cause losses to consumers because the perpetrators sell products that do not have marketing licenses or are illegal. The occurrence of losses suffered by consumers is the responsibility of the business actor to be able to provide compensation as an obligation of the business actor.

The research method used in this scientific work is the method of empirical legal research with the type of legal research. Juridical empirical recommendations are one of the discussions that analyze community priorities and norms (contributions between das sollen and das sein).

The results of this research are a form of consumer legal efforts towards misuse of vitamin $\mathrm{C}$ injections in beauty salons in Tampaksiring Subdistrict where business actors do not want to 
pay compensation to consumers and forms of efforts to resolve cases carried out by consumers, namely by asking for compensation to beauty salon businesses.

\section{KEY WORDS: Legal effort, Consumers, Injections of vitamin c}

\section{PENDAHULUAN}

\subsection{Latar Belakang Masalah}

Seiring dengan semakin berkembangnya ilmu pengetahuan dan teknologi maka kebutuhan hidup manusia pun kian berkembang. Tidak hanya kebutuhan akan sandang, papan, pangan saja. Kebutuhan akan mempercantik diri pun kini menjadi prioritas utama dalam menunjang penampilan sehari-hari. Salah satu produk kecantikan yang sangat diminati oleh wanita saat ini yaitu suntik vitamin c. keinginan untuk memiliki kulit yang putih dan mulus seperti halnya artis-artis menyebabkan banyak wanita memilih jalan instan untuk dapat memutihkan kulitnya.

Keinginan untuk mempercantik diri secara berlebihan, menyebabkan salah pengertian dalam fungsi dan penggunaan suntik putih, pada awalnya penggunaan suntik vitamin $\mathrm{c}$ hanya diperuntukkan untuk penyembuhan penyakit-penyakit kronis, namun saat ini penggunaan obat tersebut disalah artikan. Hal ini berakibat pada seseorang berbuat kesalahan dalam memilih dan menggunakan suntik vitamin c tanpa memperhatikan kondisi kulit dan pengaruh lingkungan. Hasil yang didapatkan tidak membuat kulit menjadi sehat dan cantik, tetapi malah terjadi berbagai kelainan kulit yang disebabkan oleh salah penggunaan produk tersebut.

Penggunaan suntik vitamin c untuk mendapatkan kulit yang putih sudah seperti menjadi gaya hidup yang kini terjadi pada 
masyarakat baik masyarakat kota maupun desa, tidak hanya dikalangan anak remaja tetapi juga dikalangan orang dewasa. Hal tersebut membuat para produsen alat kecantikan berlomba-lomba mempromosikan produknya agar dapat diminati oleh para pembeli, salah satunya melalui iklan seperti halnya instagram.

Pada era perdagangan bebas sekarang banyak produk kecantikan yang beredar di pasaran dengan berbagai jenis merek. Indonesia yang berada pada arus perdagangan global dituntut siap dan berani bersaing dengan produk lain menghadapi tantangan sekaligus peluang. Keinginan seorang wanita untuk selalu tampil cantik banyak dimanfaatkan oleh pelaku usaha yang tidak bertanggung jawab dengan memproduksi atau memperdagangkan produk kecantikan yang tidak memenuhi persyaratan untuk dinyatakan layak di edarkan kepada masyarakat.

Banyaknya minat konsumen untuk menggunakan jasa suntik putih pada klinik-klinik kecantikan dimanfaatkan oleh pihak yang tidak bertanggung jawab dengan menjual produk kecantikan suntik vitamin c yang palsu secara ilegal di pasaran. Hal ini tentunya bertentangan dengan Pasal 8 Ayat 1 Huruf (E) Undang-Undang Nomor 8 Tahun 1999 Tentang Perlindungan Konsumen yang menyatakan bahwa Pelaku usaha dilarang memproduksi dan/atau memperdagangkan barang dan/atau jasa yang tidak sesuai dengan mutu, tingkatan, komposisi, proses pengolahan, gaya, mode, atau penggunaan tertentu sebagaimana dinyatakan dalam label atau keterangan barang dan/atau jasa tersebut.

\subsection{Rumusan Masalah}

Berdasarkan uraian diatas maka yang menjadi fokus pembahasan adalah : 
1. Bagaimanakah bentuk perlindungan hukum bagi konsumen pengguna jasa suntik vitamin c ilegal pada salon kecantikan di Kecamatan Tampaksiring?

2. Upaya hukum apa yang dapat ditempuh oleh konsumen yang mengalami kerugian akibat suntik vitamin c illegal pada salon kecantikan di kecamatan Tampaksiring?

1.3 Tujuan Penulisan

1.3.1 Tujuan Umum

Penulisan karya ilmiah ini bertujuan untuk:

1. Mengetahui perlindungan hukum bagi konsumen pengguna jasa suntik vitamin c ilegal pada salon kecantikan.

2. Mengetahui Upaya hukum yang dapat ditempuh oleh konsumen yang mengalami kerugian akibat suntik vitamin $\mathrm{c}$ illegal pada salon kecantikan di kecamatan Tampaksiring.

\subsubsection{Tujuan Khusus}

1. Memahami perlindungan hukum bagi konsumen pengguna jasa suntik vitamin c ilegal pada salon kecantikan.

2. Memahami Upaya hukum apa yang dapat ditempuh oleh konsumen yang mengalami kerugian akibat suntik vitamin $\mathrm{c}$ illegal pada salon kecantikan di kecamatan Tampaksiring.

\section{ISI MAKALAH}

\subsection{Metode Penelitian}

Metode penelitian yang digunakan dalam tulisan ini yaitu metode penelitian hukum empiris. Metode penelitian hukum empiris adalah penelitian yang datanya didapatkan secara langsung dari masyarakat mengenai perilakunya. ${ }^{1}$ Penelitian hukum empiris terdiri atas penelitian terhadap identifikasi hukum

1 Soerjono Soekanto, 2012, Pengantar Penelitian Hukum, UI-PRESS, Jakarta, hal. 50 
dan penelitian terhadap evektivitas hukum. ${ }^{2}$ Jenis pendekatan yang digunakan dalam karya ilmiah ini adalah pendekatan yuridis empiris. Pendekatan yuridis empris adalah suatu pendekatan yang menganalisa kesenjangan antara norma dan perilaku masyarakat (kesenjangan antara das sollen dan das sein). ${ }^{3}$ Dalam tulisan ini mengkaji mengenai bagaimana pengaturan undang-undang mengenai perlindungan terhadap konsumen terkait penggunaan jasa suntik vitamin c illegal serta Upaya hukum apa yang dapat ditempuh oleh konsumen yang mengalami kerugian akibat suntik vitamin c illegal pada salon kecantikan di kecamatan Tampaksiring.

\subsection{Hasil dan Analisis}

\subsubsection{Perlindungan Hukum Bagi Konsumen Pengguna Jasa Suntik Vitamin C Ilegal Pada Salon Kecantikan}

Perlindungan hukum adalah memberikan pengayoman kepada hak asasi manusia yang dirugikan orang lain dan perlindungan tersebut diberikan kepada masyarakat agar mereka dapat menikmati semua hak-hak yang diberikan oleh hukum, atau dengan kata lain perlindungan hukum adalah berbagai upaya hukum yang harus diberikan oleh aparat penegak hukum untuk memberikan rasa aman, baik secara pikiran maupun fisik dari gangguan dan berbagai ancaman dari pihak manapun. Hukum perlindungan konsumen mengatur tentang hak dan kewajiban yang harus dipenuhi oleh pelaku usaha dan konsumen yang dijamin pemenuhannya oleh penegak hukum. Perlindungan konsumen merupakan perlindungan yang diberikan hukum

2 Bambang Sunggono, 2013, Metodelogi Penelitian Hukum, Rajawali Pers, Jakarta, hal. 42

${ }^{3}$ Fakultas Hukum Universitas Udayana, 2013, Pedoman Pendidikan Fakultas Hukum Universitas Udayana, Fakultas Hukum Universitas Udayana, Denpasar, hal. 77 
terhadap hak-hak konsumen karena konsumen dianggap dalam posisi yang lebih lemah dari pada produsen. ${ }^{4}$

Bentuk perlindungan hukum yang dapat diberikan pemerintah kepada hak-hak konsumen dalam hal ini korban penyalahgunaan suntik vitamin c pada salon kecantikan adalah perlindungan hukum preventif dan perlindungan hukum represif. Perlindungan hukum preventif yang diberikan pemerintah yaitu dengan memberikan informasi dan penyuluhan/komunikasi, dan edukasi kepada masyarakat dan pelaku usaha di bidang obat dan makanan. Perlindungan hukum represif bertujuan untuk menyelesaikan sengketa kasus yang terjadi.

Terjadinya penyalahgunaan suntik vitamin c pada salon kecantikan yang dilakukan oleh pelaku usaha kepada konsumen, pemerintah telah memberikan perlindungan hukum terkait dengan hak konsumen yang menggunakan jasa suntik vitamin $\mathrm{c}$ yaitu dalam Pasal 4 UUPK terdapat 9 point hak-hak konsumen yang harus dipenuhi oleh pelaku usaha. Penyalahgunaan suntik vitamin c illegal yang dilakukan pada salon kecantikan di kecamatan Tampaksiring tentu telah melanggar hak-hak dari pada konsumen seperti halnya hak-hak atas kenyamanan, keamanan dan keselamatan dalam mengkonsumsi barang dan atau jasa, hak untuk memilih barang dan atau jasa serta mendapatkan barang dan atau jasa tersebut sesuai dengan nilai tukar dan kondisi serta jaminan yang dijanjikan, hak untuk didengar pendapat dan keluhannya atas barang dan atau jasa yang digunakan serta hak untuk mendapatkan kompensasi, ganti rugi dan atau penggantian apabila barang dan atau jasa yang diterima tidak sesuai dengan perjanjian atau tidak sebagaimana mestinya.

${ }^{4}$ Celina Tri Siwi Kristiyanti, 2008, Hukum Perlindungan Konsumen, Sinar Grafika, Jakarta, hal.10 
Berdasarkan wawancara dengan Ayunik sebagai salah satu konsumen yang menderita kerugian akibat menggunakan jasa suntik vitamin c illegal pada salon "nona ayu" yang terletak di jalan raya sading Tampaksiring, kerugian yang dideritanya yaitu adanya gatal-gatal serta bercak-bercak merah pada kulit korban, setelah ditanyakan kepada pihak salon mereka mengatakan bahwa hal tersebut adalah reaksi dari obat yang dimasukkan kedalam tubuh namun setelah beberapa hari raya gatal dan bercak merah tersebut ternyata bertambah parah dan Ayunik mempunyai inisiatif untuk memeriksakan dirinya ke dokter kulit. Setelah mengetahui hasilnya Ayunik pun meminta ganti rugi kepada pihak salon yang menyediakan jasa suntik putih tersebut namun yang Ayunik tidak mendapatkan hasil apa-apa karena pihak salon tidak mau bertanggung jawab. Kejadian serupa juga dialami oleh korban bernama Naraswari yang menggunakan jasa suntik vitamin c pada salon kecantikan "Agung ayu" di desa Pejeng Tampaksiring. Setelah melakukan suntik vitamin c pada salon tersebut Naraswari merasakan panas pada tubuhnya dan merasakan reaksi gatal-gatal. Setelah beberapa hari gatal-gatal tersebut menjadi bercak-bercak merah seperti cacar dan menyebabkan kondisi kulit naraswasi menjadi tidak bagus. Naraswasi sudah beberapa kali datang ke salon tersebut untuk meminta ganti rugi dang anti rugi tersebut didapat namun dalam jangka waktu yang lama.

Perlindungan hak-hak konsumen pada salon kecantikan yang menyediakan suntik vitamin c secara illegal di kecamatan Tampaksiring sangat tidak diperhatikan. Hal ini terlihat dari tidak adanya tanggung jawab dari pemilik salon kecantikan untuk memberikan biaya ganti rugi maupun kompensasi kepada konsumen akibat dari penggunaan produk yang dijualnya 
tersebut. Pihak salon kecantikan selalu berkelit bahwa barang yang diperjualkannya adalah barang original padahal barang tersebut jelas-jelas barang illegal karena mereka tidak memiliki ijin untuk mengedarkan barang tersebut. Dalam penawaran awal pihak salon kecantikan menjanjikan kulit konsumennya bisa putih hanya dengan $3 x$ treatment dan biaya untuk sekali treatment adalah Rp.550.000, namun yang didapat konsumen bukan perubahan warna kulit yang menjadi putih melainkan kerusakan pada kulitnya. Hak-hak kosumen yang dilanggarnya yaitu Pasal 4 huruf a, b, c dan d.

Ketentuan Pasal 8 huruf d UUPK dinyatakan bahwa pelaku usaha dilarang memproduksi dan/ atau memperdagangkan barang dan atau jasa yang tidak sesuai dengan kondisi, jaminan, keistimewaan atau kemanjuran sebagaimana dinyatakan dalam label, etiket atau keterangan barang dan atau jasa sersebut. Pasal 8 huruf e UUPK dinyatakan bahwa Pelaku usaha dilarang memproduksi dan/atau memperdagangkan barang dan/atau jasa yang tidak sesuai dengan mutu, tingkatan, komposisi, proses pengolahan, gaya, mode, atau penggunaan tertentu sebagaimana dinyatakan dalam label atau keterangan barang dan/atau jasa tersebut. Selain itu dalam Pasal 9 ayat (1) huruf b dinyatakan pelaku usaha dilarang menawarkan, memproduksi, mengiklankan suatu barang dan/jasa secara tidak benar atau seonal-olah barang tersebut dalam keadaan baik atau baru. Tindakan yang diberikan oleh BPOM apabila terdapat pelaku usaha yang menjual produk tanpa izin edar BPOM adalah dengan memberikan sanksi administratif sesuai dengan ketentuan peraturan perundangundangan (Pasal 4 Peraturan Presiden No. 80 Tahun 2017 tentang Badan Pengawas Obat dan Makanan). Pemberian sanksi yang diberikan oleh BPOM tersebut tidak dapat menghentikan 
peredaran-peredaran produk kecantikan yang illegal hal ini terbukti dengan masih banyaknya produk kecantikan illegal yang dijual bebas di pasaran.

Pelaku usaha yang melakukan kegiatan usaha tidak sesuai dengan ketentuan yang berlaku wajib memberikan jaminan atau ganti rugi terhadap konsumen yang membeli barangnya tersebut. ${ }^{5}$ Perbuatan dari pelaku tersebut yang menyediakan jasa suntik vitamin c secara illegal tentu telah bertentangan dengan undangundang. Selain itu tidak adanya biaya ganti rugi yang diberikan oleh pelaku usaha kepada konsumen telah melanggar ketentuan pasal 19 ayat (1) UUPK yang menyatakan pelaku usaha bertanggung jawab memberikan ganti rugi atas kerusakan, pencemaran dan atau kerugian konsumen akibat mengkonsumsi barang dan atau jasa yang dihasilkan atau diperdagangkan.

Perlindungan Hukum yang dapat diberikan oleh pemerintah kepada konsumen yang mengalami kerugian akibat melakukan suntik vitamin c illegal pada salon kecantikan yaitu dengan sanksi administratif yang di kenakan kepada pelaku usaha yang melanggar Pasal 60 Ayat (2) UUPK berupa ganti rugi paling banyak Rp. 200.000.000 (dua ratus juta rupiah), sanksi administrative dianggap lrbih efektif dibandingkan dengan sanksi perdata ataupun pidana. ${ }^{6}$ Perlindungan hukum dari aspek Hukum perdata dengan memberikan Gugatan perdata terhadap pelaku usaha yang menyediakan jasa suntik vitamin c secara illegal yang menyebabkan kerugian terhadap konsumen yaitu dengan Penarikan produk kosmetik yang mengandung zat aditif

5 Gde Manik Yogiartha, 2016, Tanggung Jawab pelaku Usaha Terkait dengan Jual-Beli Telepon Seluler Tanpa Garansi, vol. 05, No. 1 : 93-100, Hal. 96, URL : https://ojs.unud.ac.id/index.php/jmhu/article/view/20613/14457

6 Celina Tri Siwi Kristiyanti, Op.cit, hal.84 
berdasarkan Pasal 63 huruf (e) UUPK. Perlindungan hukum dari aspek hukum pidana dengan memberikan hukuman pidana yang diatur dalam Pasal 204 KUHP, Pasal 205KUHP dan Pasal Pasal 382 dengan ancaman hukuman pidana penjara.

Berdasarkan hasil analisis di lapangan khususnya pada kasus suntik vitamin c illegal oleh salon kecantikan di Kecamatan Tampaksiring pemberian sanksi administrative, sanksi perdata dan sanksi pidana tidak dapat diberikan dikarenakan tidak adanya laporan dari konsumen akan tindakan dan peredaran suntik vitamin c illegal yang dilakukan oleh salon kecantikan.

\subsubsection{Upaya hukum penyelesaian kasus yang dapat ditempuh oleh konsumen yang mengalami kerugian akibat suntik vitamin c illegal pada salon kecantikan di kecamatan Tampaksiring.}

Konsumen yang mengalami kerugian akibat suntik vitamin $\mathrm{c}$ illegal pada salon kecantikan di kecamatan Tampaksiring yaitu dengan membicarakan perihal kerugian yang dideritanya kepada pelaku usaha. Konsumen dapat meminta ganti kerugian kepada pelaku usaha karena adanya kerugian yang diakibatkan oleh mengkonsumsi produk yang dijualnya. Setiap pelanggaran yang dilakukan oleh pelaku usaha yang merugikan konsumen memberikan hak kepada konsumen yang di rugikan tersebut untuk meminta pertanggungjawaban dari pelaku usaha yang 
merugikannya serta untuk menuntut ganti rugi atas kerugian yang di derita oleh konsumen tersebut. ${ }^{7}$

Upaya penyelesaian diluar pengadilan mengupakan upaya alternative yang dapat ditempuh oleh para pihak dalam menyelesaikan sengketanya. Penyelesaian sengketa diluar lembaga peradilan dipilih karena dirasa lebih menguntungkan bagi kedua belah pihak dibandingkan dengan penyelesaian sengketa melalui jalur litigasi. Selain itu penyelesaian sengketa diluar pengadilan menghasilkan penyelesaian yang saling menguntungkan (win-win solution). 8

Berdasarkan wawancara dengan korban konsumen yang menggunakan jasa suntik vitamin c illegal pada salon kecantikan di kecamatan Tampaksiring, mereka mengatakan bahwa mereka sebagai konsumen yang dirugikan selama ini tidak menindaklanjuti mengenai ganti kerugian yang harus dipenuhi oleh pelaku usaha. Mereka pernah 2-3 kali menagih ganti kerugian kepad pihak salon kecantikan namun tidak ada etikad baik dari salon kecantikan untuk mengganti uang mereka

7 Ni Komang Ayu Nira Relies Rianti, 2017, Tanggung Jawab Pelaku usaha Terhadap konsumen Dalam hal terjadinya Hortweight Ditinjau dari Undang-undang RI No. 8 Tahun 1999 tentang Perlindungan Konsumen, vol. 6, no. $4: 521-537$, URL:

https://ojs.unud.ac.id/index.php/imhu/article/view/37177/23057

8 Ketut Artadi dan I Dewa Nyoman Rai Asmara Putra, 2010, KetentuanKetentuan Hukum Perjanjian kedalam Perancangan Kontrak, Cet. I , Udayana university press, Bali, hal. 2 
sehingga mereka lebih memilih untuk membiarkan saja hal tersebut karena mereka tidak mengerti bagaimana caranya untuk dapat menyelesaikan permasalahn melalui jalur hukum serta menurut mereka jika masalah tersebut dibawa kejalur hukum nantinya mereka sendiri yang akan merasa sulit karena tidak adanya bukti-bukti yang mereka miliki.

\section{PENUTUP}

\subsection{Kesimpulan}

Berdasarkan hasil pemaparan, adapun kesimpulan dari karya ilmiah ini adalah sebagi berikut :

1. Perlindungan hukum yang diberikan kepada konsumen yaitu perlindungan secara preventif dan represif. Perlindungan hukum preventif yang diberikan pemerintah yaitu dengan memberikan informasi dan penyuluhan/komunikasi, dan edukasi kepada masyarakat dan pelaku usaha di bidang obat dan makanan. Sedangkan perlindungan hukum represif yang diberikan pada konsumen yang menggunakan jasa suntik vitamin c illegal pada salon kecantikan di Kecataman Tampaksiring yang mengalami kerugian dilindungan haknya untuk mendapatkan ganti kerugian sebagaimana disebutkan pada pasal 60 UUPK dan pelaku usaha wajib untuk membayar ganti rugi tersebut.

2. Upaya penyelesaian kasus yang ditempuh oleh konsumen jasa suntik vitamin c illegal pada salon kecantikan di Kecamaran Tampaksiring yaitu dapat melalui jalur litigasi dan non litigasi. Penyelesaian kasus yang dilakukan dengan 
meminta ganti rugi kepada pelaku usaha untuk dapat memenuhi kewajibannya membayar ganti rugi kepada konsumen dan selama ini konsumen pengguna jasa suntik vitamin c illegal pada salon kecantikan di Kecamatan Tampaksiring belum pernah melakukan upaya hukum dalam penyelesaian kasus tersebut baik melalui jalur litigasi maupun non litigasi.

\subsection{Saran}

1. Sebaiknya konsumen lebih berhati-hati dan lebih teliti memilih produk kecantikan yang akan digunakan. Lebih baik ditanyakan dan dicek terlebih dahulu apakah produk tersebut sudah terdaftar BPOM atau belum karena apabila konsumen salah memilih produk kecantikan akan berdampak dan dapat merugikan konsumen.

2. Sebaiknya pemerintah lebih memperketat peredaran produk-produk kecantikan tanpa ijin edar dan pemerintah lebih mensosialisasikan tentang pentingnya edukasi mengenai hak-hak konsumen yang didapat serta cara-cara penyelesaian yang dapat ditempuh apabila tersejadi sengketa konsumen agar hak-hak dari konsumen tersebut tidak diabaikan. Karena dalam hal ini konsumen dianggap ada pada posisi yang lebih lebah dari pada produsen.

\section{DAFTAR PUSTAKA}

\section{Buku :}

Bambang Sunggono, 2013, Metodelogi Penelitian Hukum, Rajawali Pers, Jakarta

Celina Tri Siwi Kristiyanti, 2008, Hukum Perlindungan Konsumen, Sinar Grafika, Jakarta 
Fakultas Hukum Universitas Udayana, 2013, Pedoman Pendidikan Fakultas Hukum Universitas Udayana, Fakultas Hukum Universitas Udayana, Denpasar

Ketut Artadi dan I Dewa Nyoman Rai Asmara Putra, 2010, Ketentuan-Ketentuan Hukum Perjanjian kedalam Perancangan Kontrak, Cet. I, Udayana university press, Bali

Salim H.S, 2003, Hukum Kontrak Teori dan Teknik Penyusunan Kontrak, Sinar Grafika, Jakarta

Soerjono Soekanto, 2012, Pengantar Penelitian Hukum, UI-PRESS, Jakarta

Moch. Faisal Salam, 2007, Penyelesaian Sengketa Bisnis Secara Nasional dan Internasional, Mandar Maju, Bandung

\section{Jurnal :}

Gde Manik Yogiartha, 2016, Tanggung Jawab pelaku Usaha Terkait dengan Jual-Beli Telepon Seluler Tanpa Garansi, vol. 05, No. 1 : 93-100, URL : https://ojs.unud.ac.id/index.php/jmhu/article/view/20613 $\angle 14457$

Ni Komang Ayu Nira Relies Rianti, 2017, Tanggung Jawab Pelaku usaha Terhadap konsumen Dalam hal terjadinya Hortweight Ditinjau dari Undang-undang RI No. 8 Tahun 1999 tentang Perlindungan Konsumen, vol. 6, no. 4 :521-537, URL: https://ojs.unud.ac.id/index.php/jmhu/article/view/37177 $\lcm{23057}$

Undang-Undang

Kitab Undang-Undang Hukum Perdata, Burgerlijk Wetboek voor Indonesia, Pustaka Buana, Jakarta

Kitab Undang-Undang Hukum Pidana, Moeljatno, Bumi Aksara, Jakarta

Indonesia, Undang-Undang Nomor 8 Tahun 1999 Tentang Perlindungan Konsume. Lembaran negara Republik Indonesia Tahun 1999 Nomor 42, Tambahan Lembaran Negara Nomor 3821 